Check for updates

Cite this: RSC Adv., 2019, 9, 17921

Received 24th March 2019

Accepted 1st June 2019

DOI: 10.1039/c9ra02258a

rsc.li/rsc-advances

\title{
Metastasis manners and the underlying mechanisms of ALK and ROS1 rearrangement lung cancer and current possible therapeutic strategies
}

\author{
Xing Chang, Zi Liu, Shuai Man, Annie Roys, Zengqiang Li, Daiying Zuo (iD* \\ and Yingliang $\mathrm{Wu}^{*}$
}

The rearrangements of anaplastic lymphoma kinase (ALK) and the c-ros oncogene 1 (ROS1) have both been important driving factors in non-small-cell lung cancer (NSCLC). They have already been defined in 3-5\% of NSCLC patients. ALK and ROS1 rearrangements are associated with unique clinical and pathological features, especially patients are usually younger, with milder or never smoking history, and adenocarcinoma histology. Also, they have both been found to contribute to the metastasis of NSCLC by cell migration and invasion. It has recently been recognized that the brain can be considered as a primary site for metastasis in cancers with ALK or ROS1 rearrangements. The present review summarizes the current status of NSCLC metastasis and possible mechanisms based on available evidence, and then we list possible therapeutic strategies so that an increase in control of ALK and ROS1 rearrangement of NSCLC metastases by combination therapy can be translated in an increase in overall survival and prognosis.
\end{abstract}

\section{Introduction}

Compared with other types of cancer, lung cancer has the highest morbidity and mortality. ${ }^{\mathbf{1}}$ Cancer metastasis is a complex process with multiple processes that make it one of the most difficult aspects to understand in oncology. Metastatic disease has become the main reason for the low survival rate of non-small-cell lung cancer (NSCLC). Therefore, it is important to understand the NSCLC metastasis process and its potential invasion and migration pathways. ${ }^{2,3}$ Identifying targets that inhibit lung cancer invasiveness and metastasis will help develop new anti-lung cancer strategies.

Approximately $20-25 \%$ of advanced NSCLC, particularly adenocarcinoma subtypes, have viable carcinogenic drive mutations. ${ }^{4}$ Activating mutations or translocations of the anaplastic lymphoma kinase gene (ALK) have been identified in several types of cancer, including NSCLC. ${ }^{5}$ An additional receptor tyrosine kinase (RTK) recently identified to be involved in recurring gene rearrangements in NSCLC is c-ros oncogene 1 (ROS1), an orphan receptor whose physiologic functions are still poorly understood. ${ }^{6}$ ROS1-positive patients, representing approximately 1-2\% of NSCLC cases, tend to possess typical clinicopathologic features similar to those described for ALKpositive NSCLC patients. ${ }^{6-8}$ One study showed that in Caucasian patients, the common genetic alteration in advanced NSCLC was KRAS mutations in approximately $29 \%$ of patients,

Department of Pharmacology, Shenyang Pharmaceutical University, 103 Wenhua Road, Shenhe District, Shenyang 110016, China. E-mail: zuodaiying@163.com; yingliang_1016@163.com epidermal growth factor receptor (EGFR) mutations accounting for approximately 11\%, ALK rearrangements accounting for approximately $5 \%,{ }^{9}$ and mesenchymal-epithelial transition (MET) mutations (exon 14) accounted for $4 \%,{ }^{4}$ and ROS1 rearrangement accounted for $1 \%{ }^{8}$

According to Pan et al., in patients with NSCLC who are positive for ALK or ROS1, bone metastasis accounted for $43 \%$, intrapulmonary lesions accounted for $37 \%$, pleura metastasis accounted for $30 \%$, and brain metastasis accounted for $21 \%$. These four metastases are the most common in NSCLC. ${ }^{\mathbf{1 0}}$ Another study showed that NSCLC patients aged 40 years or younger accounted for about $4 \%$ of the total number of NSCLC, of which $54.5 \%$ were women, $86.1 \%$ of patients were with adenocarcinoma, and $72.5 \%$ of patients were non-smokers. ${ }^{2}$ About $35.7 \%$ of patients with stage IV NSCLC had central nervous system (CNS) metastasis, and about 31.5\% had bone metastases. For patients with ALK-positive mutations, overall survival (OS) was 9.8 months, and patients with ALK-negative mutations had an OS of 5.6 months. ${ }^{2}$ These data suggest that it is necessary to summarize the data on ALK- or ROS1-positive NSCLC metastases, analyze the metastases mechanism, and propose some constructive treatment strategies.

\section{Metastasis manners of ALK and ROS1 rearrangement NSCLC}

\subsection{Metastasis in the CNS}

In NSCLC patients with ALK rearrangements, the CNS appears to be one of the most common metastatic sites during the 
patient's treatment, such as the brain, pia mater, and spinal cord. ${ }^{11}$ NSCLC brain metastases are generally considered to be the final stage of advanced disease and an ominous sign of disease progression and death, ${ }^{12}$ and the incidence of brain metastases is as high as $50 \%,{ }^{\mathbf{1 3 , 1 4}}$ whereas the incidence of spinal cord metastases is $0.4 \%$. Of note, $35-50 \%$ of ALK-positive patients were found to have brain metastases when participating in one study. ${ }^{\mathbf{1 1}, \mathbf{1 5 - 1 7}}$ And previous reports have described a high proportion of CNS metastases in Latin American patients at diagnosis. ${ }^{\mathbf{1 8}}$ Moreover, the brain metastasis of ALK- or ROS1positive NSCLC has not been significantly improved after treatment with drugs such as crizotinib, which is closely related to the difficulty in crossing the blood-brain barrier (BBB). ${ }^{19}$ Table 1 provides a summary of recent clinical trials for the treatment of ALK/ROS1 positive NSCLC brain metastases.

2.1.1 Leptomeningeal carcinomatosis (LC). LC is also known as leptomeningeal metastasis (LM). It occurs in approximately $3.8 \%$ of patients with unselected NSCLC ${ }^{20}$ and is seen in about $5 \%$ of patients with ALK rearrangement. Since the discovery of LC, its mechanism has not been clearly elucidated. ${ }^{21}$ There are a variety of ways by which cancer cells can invade the leptomeninges: it can be invaded directly by cells adjacent to the spinal and cranial nerves, ${ }^{22}$ also, the cells involved in the venous blood circulation can enter the space through the Batson plexus, ${ }^{23}$ and those within the arterial circulation can go across the choroid plexus to enter the leptomeninges. ${ }^{22}$ These cancer cells proliferate in suspension and they are in direct contact with pia mater, which is a thin mesenchymal tissue layer covering the nerve axis, including the spinal cord and root. Once identified, pial membrane metastasis may invade the parenchyma and produce focal nerve damage. ${ }^{24}$ In a previous study, it was observed that patients with LC usually had very poor prognosis, and neither chemotherapy nor targeted therapy was able to significantly improve the outcomes. The median survival of untreated patients was only 4-6 weeks. ${ }^{25}$

2.1.2 Intradural extramedullary spinal cord metastases (IESCM) and intradural spinal cord metastases (ISCM). NSCLC often metastasizes to the intracranial central nervous system, but rarely metastasizes to the spinal cord, which occurs in only about $2 \%$ of NSCLC patients with less than 150 cases described in the medical case literatures. ${ }^{26}$ According to previous findings, the spinal cord metastasis may have been caused by dissemination and seeding via the cerebrospinal fluid..$^{26-28}$

IESCM, also known as spinal cord pial metastases, are a special clinical manifestation of LC-related spinal cord involvement. ${ }^{29,30}$ Tumor cells spread and spread in the subarachnoid space outside the spinal cord, resulting in a series of symptoms of spinal cord and spinal nerve root involvement, manifested as metastatic spinal cord compression syndrome. The incidence of such metastasis is low, but the clinical symptoms of patients are heavy. Once they occur, the quality of life of patients is seriously affected, and the prognosis is extremely poor. ${ }^{31}$

Like LC, ISCM is a rare disease, but ISCM is common in lung cancer and breast cancer metastasis, while cervical, thoracic and lumbar spine are also affected. In NSCLC, ISCM occurs in $2-4.2 \%$ of patients. ${ }^{11,32,33}$ Justin and colleagues recently reported the ISCM in the first ALK-positive NSCLC patient. ${ }^{11}$ In their study, 3 out of 96 other ALK-positive patients were also diagnosed with ISCM, but LC was not found in these patients. The average time from diagnosis of NSCLC to ISCM in all patients exceeded 15 months, indicating that the longer the survival period, the greater the risk of developing ISCM. ${ }^{11}$

Most reports are retrospective and limited in scale, so there is no uniform conclusion on the best treatment for patients with ISCM. ${ }^{32,33}$ In general, management strategies already include radiation therapy, surgery resection, chemotherapy, or a combination of the above methods. ${ }^{33}$ For patients with intramedullary tumors, ISCM patients had the worst results, with a median survival of approximately 4 months from the time of diagnosis. ${ }^{34}$

\subsection{Bone metastasis}

Kuijpers et al. in their study identified 784 KRAS+, 160 EGFR+ (exon 19del, exon 21 L858R), $42 \mathrm{ALK}+$ and 1008 triple negative tumors. From this study, they reported that the bone was the most common metastatic organ (34\%). ${ }^{35}$ Skeleton is one of the common metastatic sites of lung cancer. Bone metastasis of lung cancer interferes with local bone homeostasis, reduces bone formation or/and increases bone resorption. ${ }^{36,37}$ Patients with lung cancer and bone metastases have a poor prognosis with a median survival of less than 1 year. ${ }^{38}$ The mechanism of NSCLC bone metastasis is not fully understood, but there is evidence that lung cancer cells invade the bone surface and through the secretion of certain growth factors or cytokines, thereby destroy the steady state of the bone. ${ }^{39}$

Receptor Activator of Nuclear Factor- $\kappa$ B Ligand (RANKL) plays a critical role in the formation, survival, and function of osteoclasts. Previous studies showed that RANKL is very important for the processes leading to bone metastases proceeded to skeletal destruction. ${ }^{40}$ The RANK receptor is responsible for RANKL functions, it is expressed on osteoclasts and osteoclast precursors, and is inhibited by the soluble decoy receptor osteoprotegerin (OPG).41,42 Using diverse signals including interleukin (IL)-1 $\beta$, IL-6, IL-8, IL-11, IL-17, macrophage inflammatory protein-1 alpha (MIP1 $\alpha$ ), tumor necrosis factor- $\alpha$, parathyroid hormone-related protein (PTHrP), and prostaglandin E2 (PGE2) metastatic tumor cells cause an upregulation of RANKL within bone stromal cell. ${ }^{43}$ Subsequently, in response to PTHrP, IL-1, PGE2, Dickkopf-related protein 1 (DKK-1) or epidermal growth factor (EGF), tumor involvement in bone can also down-regulate local OPG levels in stroma and osteoblasts. ${ }^{44}$ In any case, an increase in the ratio of RANKL to OPG in the local bone microenvironment can lead to invasive osteolytic bone destruction.

Some preclinical studies have demonstrated that the inhibition of RANKL leads to a significant reduction of bone tumor burden. Moreover, the combination of RANKL inhibitors with chemotherapy not only targets the bone environment to treat NSCLC bone metastases but also supports further clinical evaluation, thus establishing that the combinatorial approach is better than the use of either drug alone. ${ }^{45}$ 
Table 1 Treatment of ALK/ROS1 positive NSCLC brain metastasis with TKIs-summary of the latest clinical trials ${ }^{a}$

\begin{tabular}{|c|c|c|c|c|c|c|c|c|}
\hline Agent & $\begin{array}{l}\text { Molecular } \\
\text { targets }\end{array}$ & $\begin{array}{l}\text { Clinical trials. gov } \\
\text { identifier }\end{array}$ & Patients & $\begin{array}{l}\text { Clinical } \\
\text { stage }\end{array}$ & Dosage & $\begin{array}{l}\text { Complete intracranial } \\
\text { response rate }(\%)\end{array}$ & $\begin{array}{l}\text { Intracranial } \\
\text { PFS }\end{array}$ & Reference \\
\hline Crizotinib & $\begin{array}{l}\text { ALK/ROS1/ } \\
\text { MET }\end{array}$ & $\begin{array}{l}\text { NCT01154140 } \\
\text { (PROFILE 1014) }\end{array}$ & 39 & $\begin{array}{l}\text { Phase III } \\
\text { trial }\end{array}$ & $\begin{array}{l}250 \mathrm{mg} \text { per } \\
\text { os twice daily }\end{array}$ & $\begin{array}{l}12 \text { weeks: } 85 \% \text {, } \\
24 \text { weeks: } 56 \%\end{array}$ & 9 months & 77 \\
\hline Ceritinib & ALK/ROS1 & $\begin{array}{l}\text { NCT01828099 } \\
\text { (ASCEND-4) }\end{array}$ & 54 & $\begin{array}{l}\text { Phase III } \\
\text { trial }\end{array}$ & $\begin{array}{l}750 \mathrm{mg} \text { per } \\
\text { os daily }\end{array}$ & $\begin{array}{l}24 \text { weeks or } \\
\text { longer: } 46.3 \% \\
(n=54)\end{array}$ & $\begin{array}{l}10.7 \text { months } \\
(n=189)\end{array}$ & 141 \\
\hline Brigatinib & ALK/ROS1 & NCT02094573 & 73 & $\begin{array}{l}\text { Phase II } \\
\text { trial }\end{array}$ & $\begin{array}{l}180 \mathrm{mg} \text { per } \\
\text { os daily }\end{array}$ & - & 18.4 months & 145 \\
\hline Lorlatinib & ALK/ROS1 & NCT01970865 & 81 & $\begin{array}{l}\text { Phase II } \\
\text { trial }\end{array}$ & $\begin{array}{l}100 \mathrm{mg} \text { per } \\
\text { os daily }\end{array}$ & $20 \%$ & - & 146 \\
\hline Ensartinib & ALK/ROS1 & NCT01625234 & 14 & $\begin{array}{l}\text { Phase I/II } \\
\text { trial }\end{array}$ & $\begin{array}{l}225 \mathrm{mg} \text { per } \\
\text { os daily }\end{array}$ & $57 \%$ & 16.6 months & 120 \\
\hline
\end{tabular}

\subsection{Lymph nodes metastasis}

Lymph nodes (LNs) are common site of metastasis and it is important for triggering an anti-tumor immune response. Therefore, cancer cells must evade the immune response before they can be transferred to LNs. $^{46}$ The process of lymphatic metastasis begins with the orchestration of lymphangiogenesis and the preparation of a premetastatic niche. ${ }^{46}$ A premetastatic niche is a LN microenvironment favorable for tumor growth. Cancer cells then invade tumor-associated lymphatic vessels at the primary site on their way to tumor-draining LNs (TDLNs), where they survive and grow. ${ }^{46}$

The mechanism by which LN lymphangiogenesis results in metastasis has not yet been identified, but one hypothesis suggests that increased lymph flow which is an effect of LN lymph angiogenesis may lead to a more efficient delivery of cancer cells to LNs and distant organs, and the expression of both vascular endothelial growth factor (VEGF)-C and VEGF-D have been linked with increased LN metastasis. ${ }^{46}$ A study conducted by Zhang et al. showed that the frequency of lung cancer patients with lymph node metastasis expressing ALK and ROS1 fusions was $10.7 \%$ and $1.8 \%$ respectively. ${ }^{47}$

Gao et al. analyzed ALK fusions from paired primary and metastatic lymph node tumors in 78 lung cancer patients who had not received small molecular tyrosine kinase inhibitors (TKIs), and proved that the ALK fusions of primary lung cancers and those in corresponding metastatic lymph node tumors are highly consistent. ${ }^{48}$

\subsection{Ovarian metastasis}

Ovarian metastasis from lung cancer is extremely rare, approximately $0.3-0.4 \%$ of metastatic ovarian tumors metastasize from lung cancer, and about $33 \%$ of the lung carcinomas that metastasize to the ovary are adenocarcinomas. ${ }^{49-51}$ Ovarian metastasis has been observed to be more common among young women with lung cancer, this is a feature usually common in ALK- and ROS1-positive patients. A few cases of ovarian involvement from ALK-positive NSCLCs have been reported. Jing and colleagues presented a case of a 41 year-old woman who was initially diagnosed with NSCLC adenocarcinoma on histology. ${ }^{52}$ After receiving a 6-course first-line chemotherapy and 8-course maintenance therapy, emergency surgery was performed and the resected tissues were sent for pathological evaluation and immunohistochemistry (IHC) analysis. The pathological diagnosis of the resected ovarian was metastatic pulmonary adenocarcinoma and a positive indication for ALK rearrangement was found in a metastatic ovarian lesion. Hence, it was deduced that specimens from metastatic lesions and primary tumors are equally suitable for use in detecting ALK rearrangement for therapeutic strategies in patients with advanced NSCLC. After the detection of ALK rearrangement, crizotinib was administered, and the disease remained stable after 10 months of crizotinib therapy. ${ }^{52}$

Although several cases of ovarian metastasis involving ALK rearrangement have been presented, only one case of bilateral ovarian metastasis from ROS1 translocated lung adenocarcinoma has been reported so far. Franchina et al. presented a case of a 43 years old never smoking woman diagnosed with metastatic lung adenocarcinoma. ${ }^{53}$ Transvaginal ultrasound indicated the presence of dysfunctional cysts in both ovaries. After undergoing EGFR, KRAS and ALK testing, no actionable mutation was found and she commenced first-line chemotherapy with cisplatin-pemetrexed. After 19 months FISH assay detected the presence of ROS1 rearrangement. They reported a lengthy progression-free survival (PFS) on pemetrexed-based chemotherapy, but after re-staging and pathological confirmation of ROS1 translocation, she enrolled in a phase II study of crizotinib.

\subsection{Choroidal metastasis}

Lung cancer has been reported to metastasize to the eye in $0.2 \%$ to $7 \%$ of patients based on clinical studies. ${ }^{54}$ There is abundant blood supply to the choroid, this may present a suitable microenvironment for cancer cell growth. Thus, the choroid is the most common ocular tissue affected by metastatic disease. ${ }^{55,56} \mathrm{Lu}$ and colleagues reported a case of a patient with ROS1-rearranged NSCLC that presented with choroidal metastases and did not respond to initial chemotherapy but had a rapid and complete 
response to crizotinib. ${ }^{57}$ Feng and colleagues reported a similar case in an ALK-positive patient. ${ }^{58}$ However, another study presents a case where the metastatic tumor was first responsive to crizotinib and a decrease in tumor size and improved vision was observed. ${ }^{59}$ The condition was stable until the 16th month of crizotinib therapy when a new superior metastasis was detected. Crizotinib therapy was continued for 2 weeks and then discontinued after the patients' vision worsened. Treatment with the second generation anti-ALK agent, brigatinib was initiated. After brigatinib treatment, the patient's ocular symptoms were resolved and vision improved. ${ }^{59}$ Also, the second generation ALK inhibitors alectinib and ensartinib have shown to be effective against of crizotinib resistant choroidal metastasis in patients with ALK NSCLC. ${ }^{56,59}$

\subsection{Other metastasis}

Most incidence of NSCLC is accompanied by multiple metastases (pleura, adrenal gland, muscle, bone, liver). This is also reflected in the pathology of patients with ALK-positive NSCLC. ${ }^{60}$ An increase in the incidence of liver metastases in ALK-positive patients was recently reported. ${ }^{61,62}$ Mikes et al. observed a higher incidence of pericardial, pleural, and liver metastasis in ALK-positive patients compared to patients without an EGFR, KRAS or ALK oncogene abnormality. ${ }^{63}$ Beside that Di Ma et al. analyzed the clinicopathological features and treatment outcomes of 52 patients with ALK-positive advanced NSCLC admitted to the Oncology Department of the Cancer Hospital of the Chinese Academy of Medical Sciences. They reported that pleural metastases occurred in $36.5 \%$ of patients. ${ }^{64}$ But no reports of relevant mechanisms were found.

\section{The metastasis mechanisms of ALK and ROS1 rearrangement NSCLC}

A novel circRNA F-circEA-2a produced from the EML4-ALK fusion gene which is mainly located in the cytoplasm was identified, although F-circEA-2a does not affect the proliferation of NSCLC cells, it can significantly affect the migration and invasion of cancer cells. ${ }^{65}$ It has been reported that metformin increases cell sensitivity to crizotinib by inhibiting cell proliferation and invasion to promote apoptosis, which is likely to be related to downregulation of insulin-like growth factor 1 receptor (IGF-1R) signaling. ${ }^{66}$ Epithelial-mesenchymal transition (EMT) is closely related to the invasion and metastasis of cancer cells, previous findings suggest that EMT was acquired during ALK inhibitor therapy. ${ }^{67}$ And this process is related to EMT-related proteins Ecadherin and vimentin. ${ }^{68}$ As another major regulator of EMT, slug is up-regulated by up-regulation of hypoxia inducible factor (HIF)-1 $\alpha$ during hypoxia. Expression of EML4-ALK also increases expression of EMT-inducing transcription factors, snail and slug, suggesting that EMT is ongoing. ${ }^{69}$ And blocking extracellular regulated protein kinases (ERK) 1/2 can antagonize cell migration mediated by EML4-ALK. ${ }^{70}$ An and colleagues have shown that Crk-like protein (CRKL) is a key downstream response factor for ALK. Although knockdown of CRKL has no effect on ALK phosphorylation and expression in cells, it hinders the expression of the downstream genes RAS and RAC1 of ALK, which leads to a decrease in cell viability and migration ability. ${ }^{71}$ In addition, studies have shown that by directly targeting zinc finger E-boxbinding homeobox 1 (ZEB1) and indirectly up-regulating Ecadherin, high expression of miR-200c significantly inhibits proliferation, migration and invasion of NSCLC cells. ${ }^{72}$

In the study of invasion and metastasis of the high expression of ALK or ROS1 NSCLC, Jun et al. observed that ROS1 cells expressing the CD74-ROS1 fusion were highly invasive in vitro and metastatic in vivo. Expression of CD74-ROS1 resulted in the phosphorylation of the extended synaptotagmin-like protein ESyt $1 .^{73}$ A recent study conducted by our group further demonstrated that CD74-ROS1 or CD74-ROS1 G2032R mutations induce cell EMT in A549 cells by constructing an A549-CD74ROS1 crizotinib-resistant cell line with the G2032R mutation. This promotes migration and increases expression of matrix metalloproteinase (MMP)-9 and Twist1 transcription factors. ${ }^{74}$ Fig. 1 summarizes possible pathways for ALK/ROS1 positive NSCLC invasion and metastasis.

\section{Conventional treatments}

The side effects caused by conventional chemotherapy make it very limited in controlling ALK- or ROS1-positive NSCLC metastasis compared to targeted therapy and immunotherapy. Due to cumulative toxicity, patients often fail to receive multiple courses of conventional chemotherapy including platinumbased chemotherapy, pemetrexed chemotherapy or both, while targeted therapy and immunotherapy can be more easily maintained. ${ }^{75}$ Increasing the chemotherapy cycle can significantly prolong progression-free survival (PFS), but the OS cannot be improved, while adverse reactions increase, and quality of life declines. ${ }^{76}$ The PROFILE 1014 phase III study reported a median PFS of 7.0 months in patients receiving conventional chemotherapy (pemetrexed plus cisplatin carboplatin), which was significantly lower than patients receiving crizotinib with a median survival of 10.9 months. ${ }^{77}$ In patients who received bevacizumab plus platinum-containing dual-drug chemotherapy in the first-line, and bevacizumab plus pemetrexed for dual-drug maintenance therapy prolonged PFS compared with bevacizumab monotherapy maintenance therapy. ${ }^{78}$ Even if maintenance treatment can prolong PFS, OS cannot be prolonged and the quality of life cannot be improved. ${ }^{79}$

\section{Treatments targeting metastasis of ALK and ROS1 rearrangement NSCLC}

\subsection{Crizotinib}

Crizotinib (Xalkori, PF-02341066) is an oral small-molecule inhibitor which can inhibit the tyrosine kinases ALK, ROS1, and MET factor and it was also the first direct ALK inhibitor tested in humans with ALK rearrangement-positive lung cancer. ${ }^{\mathbf{8 0 , 8 1}}$ Reports on the use of crizotinib for CNS metastasis are contradictory and the mechanisms involved are not fully understood..$^{\mathbf{2}-\mathbf{8 4}}$

However, in the PROFILE 1014 phase III study, a comparison study between crizotinib and chemotherapy ${ }^{85}$ showed that 
intracranial efficacy was prospectively assessed using protocolspecified brain imaging at baseline in patients with brain metastasis, crizotinib showed a clinically and statistically significant improvement in efficacy compared to platinumpemetrexed chemotherapy. ${ }^{77,86}$ As a result of this study, crizotinib was approved as first-line agent by the FDA in $2013 .{ }^{87,88} \mathrm{In}$ another study, crizotinib had less effect on the control of CNS metastasis, this is mainly due to the role of the BBB, because crizotinib is a known P-glycoprotein substrate that can be excreted by the BBB. ${ }^{89}$ Toyokawa et al. also observed that the concentration of crizotinib in cerebrospinal fluid was extremely low, ${ }^{90}$ thus suggesting that crizotinib may not reach the therapeutic concentration that should be found in the CNS. Takeda et al. reported that isolated radiotherapy of CNS lesions in patients whose disease had progressed on crizotinib led to favorable outcomes following resumption of crizotinib therapy, indicating that a combination of isolated radiotherapy with crizotinib therapy may improve the prognosis of patients with CNS metastases. ${ }^{9}$

Zhang et al. reported a case in which the use of crizotinib combined with surgery, whole brain radiotherapy (WBRT) and residual focus supplemental radiotherapy for the treatment of ROS1-positive lung adenocarcinoma with symptomatic brain metastases was successful. ${ }^{91}$ If the concentration of crizotinib in cerebrospinal fluid can be monitored regularly, crizotinib combined with WBRT may be an alternative strategy for CNS metastasis in patients with ROS1-positive NSCLC. ${ }^{22}$

Crizotinib has proven to be effective against LC because disruption of the BBB with WBRT results in elevated concentrations of crizotinib in the cerebrospinal fluid. ${ }^{93}$ The OS of patients treated in this manner is approximately $\sim 5$ years. ${ }^{92}$ There have even been reports of profound effects of ALK inhibitors on EML4-ALK-positive lung cancer patients, and almost all bone metastases and lymph node metastases disappeared shortly after crizotinib administration. ${ }^{94}$

\subsection{Ceritinib}

Ceritinib (Zykadia, LDK378) is a second-generation, smallmolecule, ATP-competitive ALK tyrosine kinase inhibitor (TKI). It is structurally different from crizotinib and has proven to be 20 times more effective than crizotinib..$^{95}$ Ceritinib is effective in patients with metastatic NSCLC including but not limited to brain metastasis. It showed significant CNS activity ${ }^{96}$ compared to the first-generation ALK inhibitor. Its anti-brain metastasis effect in ALK-positive NSCLC, suggests it has a better BBB penetrating ability. Ceritinib is known to have $15 \%$ CSF penetration. ${ }^{97}$ This is also verified in ASCEND-1 Trial (\#8003). ${ }^{96}$

Moreover, studies have shown that ceritinib can prolong PFS in patients. This study envisions the application of ceritinib in ROS1 rearranged NSCLC patients. ${ }^{98}$ Ceritinib also showed excellent anti-IESCM activity in patients with ALK-positive NSCLC. ${ }^{99}$ Although there is a current lack of case support, but evidence from pathology reports and some preclinical studies, suggest that second-generation ALK inhibitors, especially ceritinib, may be a good choice for treating LC. ${ }^{97}$ It is worth noting that ceritinib may be highly effective in patients whose disease has progressed on crizotinib and has metastasized regardless of where the metastatic site is. ${ }^{100}$

\subsection{Alectinib}

Alectinib (CH5424802/RO5424802) is a highly selective secondgeneration ALK inhibitor. In the phase I/II trial in the United States, alectinib has significant activity on brain metastases of ALK rearranged NSCLC with an initial total response rate of 52\%. ${ }^{101-103}$ In November 2017, the FDA approved the use of alectinib for first-line treatment of patients with ALK-positive metastatic NSCLC. ${ }^{104}$ This is based on the 3rd clinical trial test (ALEX). In the ALEX trial, $45 \%$ of patients in the crizotinibtreated group developed CNS progression and this number is only $12 \%$ in the alectinib-treated group. ${ }^{105}$

When it comes to LC or ISCM, a large number of experimental conclusions tells us that alectinib has a beneficial effect on CNS lesions. ${ }^{96,101,106-108}$ In the report by Justin et al., alexinib showed significant anti-tumor activity in ALK-positive LC patients. In addition, they found that alectinib had a good control of patients with recurrent CNS disease after treatment with crizotinib and ceritinib. ${ }^{106}$ Alectinib's phase II global study demonstrated its effective clinical activity in patients with advanced ALK-positive NSCLC. Alectinib also led to a reduction in CNS metastasis, and CNS objective response rate in patients with CNS metastases is $57 \%$, and the CNS complete response rate is $27 \% .{ }^{107}$

Therefore, as a more effective ALK receptor inhibitor, its real therapeutic advantage lies in the treatment of CNS metastatic disease. Its mechanism is that, unlike other ALK inhibitors, alectinib is not a substrate for P-glycoprotein, so it can reach higher concentrations in the cerebrospinal fluid. ${ }^{102}$ Unfortunately, there are few reports on the treatment of ROS1-positive NSCLC with alectinib.

\subsection{Brigatinib}

The targeted therapy drug brigatinib (AlunbrigTM) for patients with metastatic NSCLC was granted accelerated approve by the US Food and Drug Administration (FDA) in April 2017. ${ }^{109}$ In patients with ALK-positive NSCLC who had not previously received an ALK inhibitor, PFS was significantly longer among patients who received brigatinib than among those who received crizotinib. In a phase 3 trial, brigatinib, as compared with crizotinib, had superior efficacy against systemic and intracranial disease. ${ }^{110}$ So brigatinib is another secondgeneration ALK inhibitor that has enhanced antitumor activity and broad anti-mutation activity compared to other secondgeneration ALK inhibitors. ${ }^{111}$

Importantly, according to the phase I/II trial results, patients with brain metastases had an objective response rate of $67 \%$ and a median progress free survival of 15.6 months or even higher, indicating that brigatinib may have excellent CNS activity. ${ }^{112}$

\subsection{Lorlatinib}

Lorlatinib (PF-06463922), a third-generation small molecule TKI, is a novel, reversible, ATP-competitive inhibitor of ALK and ROS1. Inhibition acts by mediating the disruption of the 


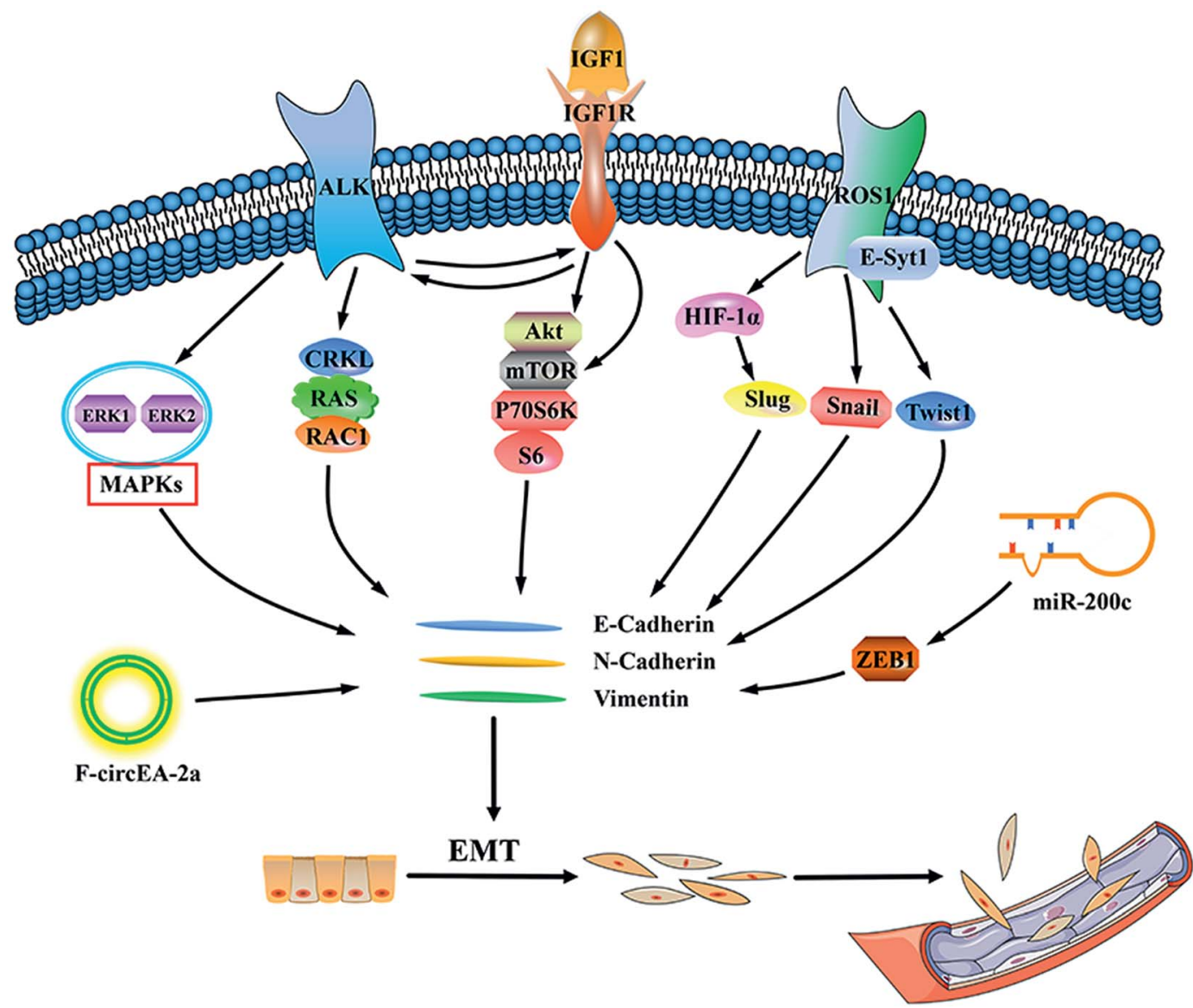

Fig. 1 Diagram of the possible pathways for ALK/ROS1 rearrangement NSCLC invasion and metastasis. IGF1, insulin-like growth factor 1; IGF1R, insulin-like growth factor 1 receptor; ERK, extracellular signal-regulated kinases; MAPK, mitogen-activated protein kinases; CRKL, Crk-like protein; RAS, RAC1 (downstream genes of ALK); mTOR, mammalian target of rapamycin; E-Syt1, extended synaptotagmin-like protein 1; HIF-1 $\alpha$, hypoxia inducible factor-1 $\alpha$; ZEB1, zinc finger E-box-binding homeobox 1; EMT, epithelial-mesenchymal transition.

signaling pathways of ALK and ROS1. ${ }^{113}$ Lorlatinib has been approved for the treatment of ALK-positive NSCLC in the United States and Europe. ${ }^{114}$ It is important that lorlatinib also has a good effect on patients with brain metastases through the BBB. ${ }^{115}$ Animal studies have shown that lorlatinib is more effective against CNS lesions than alectinib. ${ }^{115}$ Clinical studies showed that at any time point, the cumulative incidence of CNS progression and non-CNS progression was lower in the alectinib group than in the crizotinib group. ${ }^{\mathbf{1 0 5 , 1 1 6 , 1 1 7}}$

NCT01970865 was an open-label multicentre phase I/II study $^{118}$ which demonstrated that alectinib is systemically active in patients with advanced ALK- or ROS1-positive NSCLC and can prevent intracranial metastasis. Therefore, lorlatinib is very promising as the treatment of choice for ALK- or ROS1positive NSCLC patients with tumor metastasis.

\subsection{Ensartinib}

Ensartinib is a new generation of uniquely effective ALK inhibitors with good clinical activity. Ensartinib not only inhibits wild-type ALK, but also inhibits ALK-mutants (F1174, C1156Y, L1196M, S1206R, T1151, and G1202R mutants). ${ }^{119}$ Phase I/II study of ensartinib (X-396) demonstrated that in 14 patients with brain metastases, brain tumors disappeared completely in 2 patients, tumors in 7 patients were significantly reduced, and it had an intracranial response of $64.3 \%$. There were 4 patients with stable tumor progression, so the total brain tumor control rate was as high as $92.9 \%$. Therefore, its remarkable CNS activity is worthy of our attention. ${ }^{120}$

\subsection{Erlotinib}

Although erlotinib is a selective inhibitor of EGFR tyrosine kinase domain, it has been reported that it may have improved CNS metastasis activity, the CSF penetration rate of erlotinib in patients with CNS metastases is $5.1 \%$, which suggests that it can be one of the options for the treatment of CNS metastasis in NSCLC. ${ }^{121}$ The overall response rate is about $50 \%$, which is better than standard second-line chemotherapy ${ }^{122}$ In addition, there are reports recommending the use of bevacizumab in combination with erlotinib as a first-line treatment for brain metastases. ${ }^{123}$

\subsection{Immunotherapy}

Several research groups have found that programmed cell death 1 ligand 1 (PD-L1) expression is associated with driving mutations such as EGFR mutations and EML4-ALK fusion genes in NSCLC and that overexpression of EML4-ALK fusion gene increases PD- 
L1 expression via a common downstream pathway mediated by mitogen-activated protein kinases/extracellular signal-regulated kinases (MAPK/ERK) and phosphoinositide 3-kinases-protein kinase B (PI3K-AKT). ${ }^{124}$ Hong et al. found that ALK fusion protein-mediated PD-L1 increased T cell apoptosis in tumor cell and dendritic cells-cytokine induced killer (DC-CIK) cell coculture systems. ${ }^{\mathbf{1 2 4 - 1 2 6}}$ One report claims that clinically, in patients with NSCLC, there are fewer studies on programmed cell death protein 1 (PD-1) axis inhibitors in patients with ALK mutations. However, patients with EGFR mutations have a lower response rate (about 10\%) to PD-1 axis inhibitors. ${ }^{127}$ Anti-PD-L1 drugs include atezolizumab and durvalumab, as well as antiPD-1 drugs, nivolumab and pembrolizumab have been approved in patients with NSCLC. ${ }^{\mathbf{1 2 8}}$ In one study, the addition of atezolizumab to bevacizumab plus chemotherapy (carboplatin plus paclitaxel) significantly improved PFS and OS among patients with metastatic non-squamous NSCLC, regardless of PDL1 expression and EGFR or ALK genetic alteration status. ${ }^{129}$ Compared with docetaxel, atezolizumab has a higher efficacy in advanced and metastatic NSCLC progressing. ${ }^{130,131}$ The US Food and Drug Administration approved nivolumab in March 2015 for the treatment of patients with metastatic squamous NSCLC. ${ }^{\mathbf{1 3 2}}$ Moreover, in patients with advanced squamous cell NSCLC, nivolumab was significantly superior to docetaxel in OS, response rate, and PFS regardless of PD-L1 expression levels. ${ }^{133}$ Pembrolizumab, a monoclonal antibody that binds to the PD-1 receptor, is approved for the treatment of patients with metastatic non-squamous NSCLC who do not have EGFR or ALK genomic tumor mutations. ${ }^{\mathbf{1 3 4}}$ And a sustained intracranial response was achieved in 33\% of NSCLC patients. ${ }^{\mathbf{1 3 5}}$ Similarly, Kamath et al. reported an intracranial response rate of $20-30 \%$ in patients with melanoma or NSCLC brain metastases treated with the PD-1 inhibitor pembrolizumab. ${ }^{136}$ These studies have shown that pembrolizumab was well tolerated and that intracranial and extracranial responses were highly consistent. The PD-1/PD-L1 inhibitor nivolumab and the cytotoxic $\mathrm{T}$ lymphocyte-associated antigen-4 (CTLA-4) inhibitor ipilimumab are currently the most widely used combined immunotherapy. Nivolumab and ipilimumab are the first PD-1/CTLA-4 combinations to show safety and superior efficacy in metastatic melanoma, ${ }^{\mathbf{1 3 7}}$ however these types of combination therapy failed to improve PFS and OS in metastatic NSCLC and is not recommended for the treatment of relapsed or metastatic NSCLC. ${ }^{\mathbf{1 3 8}}$

\section{Discussion}

In this review, we thoroughly summarized the invasion and metastasis pathways of ALK and ROS1 overexpressed NSCLC and current possible therapeutic strategies. Although NSCLC patients with ALK and/or ROS1 mutations account for a small fraction of the overall NSCLC, they have become a research hotspot in recent years. Compared with other parts of the metastasis, the occurrence of brain metastasis makes treatment difficult because of the existence of the $\mathrm{BBB},{ }^{19}$ however, after crizotinib, many second-generation TKIs have been developed, such as ceritinib, alectinib, etc., all of which can cross the BBB and maintain a certain concentration in CSF, which improves the prognosis of patients with NSCLC brain metastases. ${ }^{95,101}$ From the perspective of historical treatment, chemotherapy plus stereotactic radiosurgery (SRS), WBRT and surgery were the mainstream treatments of brain metastases, ${ }^{139}$ but we now have more choices. For example, erlotinib plus bevacizumab may be used as first-line therapy for brain metastasis (BM) in NSCLC, even in patients with BM-related neurologic symptoms and multiple $\mathrm{BMs} ;{ }^{\mathbf{1 2 3}}$ microsurgical resection plus SRS is a good treatment for metastatic intramedullary spinal cord tumors, while also avoiding damage to surrounding tissues; ${ }^{139}$ crizotinib combined with intrathecal chemotherapy may have a better effect on pia mater disease in patients with ALK-positive NSCLC $;{ }^{\mathbf{1 4 0}}$ pemetrexed is used as a control in some clinical studies and has been shown to be less effective than TKIs, but does not rule out the possibility of combination therapy. ${ }^{141}$ And also some immunotherapies have provided us with new ideas, in patients with PD-L1-negative tumors, the combination of pembrolizumab with chemotherapy showed high levels of activity compared to chemotherapy alone $\mathrm{in2,143}^{\mathbf{1 4 2}}$

Despite we can't solve the problem of lung cancer metastasis right away, we can take a different approach to get a better prognosis. The new ALK/ROS1 inhibitor should not only be more effective than crizotinib and able to inhibit the clinically relevant acquired resistance mutations in ALK or ROS1 but also confer sustained clinical activity in the CNS. We should focus more on reducing drug toxicity and reducing related side effects. Although diseases such as brain metastasis are serious and complicated diseases, the management of NSCLC in recent years has extended the life of patients, and it is necessary to develop more personalized treatment plans and continuously optimize treatment plans.

\section{Conclusion \& future perspectives}

Cases of tumor metastasis in ALK/ROS1 rearrangement NSCLC patients are common, which are associated with acquired drug resistance, once the disease is present, the prognosis is poor, and the mortality is high. Therefore, we summarized the most common metastasis manners for ALK/ROS1 rearrangement NSCLC and its mechanisms based on the existing researches and intended to provide ideas for future researches. We also reviewed the latest clinical trial data which give a clearer understanding of research progress in developing the most effective treatment options.

Crizotinib combined with WBRT may have a better effect on the ROS1-positive lung adenocarcinoma with symptomatic brain metastases; after treatment with crizotinib and ceritinib, alectinib can effectively control recurrent central nervous system diseases; erlotinib plus bevacizumab can be used as first-line treatment for BM in ALK-positive NSCLC. We suggest more researches should focus on the related mechanisms of increased invasion and metastasis rate caused by ALK/ROS1 rearrangement NSCLC and exploring personalized treatment strategies is urgent.

\section{Conflicts of interest}

The authors declare that they have no financial, personal or professional conflict of interest. 


\section{Acknowledgements}

This work was funded by the National Natural Science Foundation of China (81872394), Young and middle age backbone personnel training program of Shenyang Pharmaceutical University (ZQN2015003) and Liaoning BaiQianWan Talents Supporting Program (2016921065).

\section{References}

1 S. Sun, J. H. Schiller and A. F. Gazdar, Nat. Rev. Cancer, 2007, 7, 778-790.

2 L. C. Christine and A. W. Robert, Science, 2011, 331, 15591564.

3 P. S. Steeg, Nat. Med., 2006, 12, 895-904.

4 J. Mazieres, J. P. Merlio, D. Debieuvre, J. Mosser, H. Lena, L. Ouafik, B. Besse, I. Rouquette, V. Westeel, F. Escande, I. Monnet, A. Lemoine, R. Veillon, H. Blons, C. AudigierValette, P. P. Bringuier, R. Lamy, M. Beau-Faller, J. L. Pujol, J. C. Sabourin, F. Penault-Llorca, M. G. Denis, S. Lantuejoul, F. Morin, Q. Tran, P. Missy, A. Langlais, B. Milleron, J. Cadranel, J. C. Soria and G. Zalcman, Lancet Oncol., 2016, 387, 1415-1426.

5 M. Soda, Y. L. Choi, M. Enomoto, S. Takada, Y. Yamashita, S. Ishikawa, S. Fujiwara, H. Watanabe, K. Kurashina, H. Hatanaka, M. Bando, S. Ohno, Y. Ishikawa, H. Aburatani, T. Niki, Y. Sohara, Y. Sugiyama and H. Mano, Nature, 2007, 448, 561-566.

6 J. F. Gainor and A. T. Shaw, Oncologist, 2013, 18, 865-875.

7 K. Bergethon, A. T. Shaw, S. H. Ou, R. Katayama, C. M. Lovly, N. T. McDonald, P. P. Massion, C. Siwak-Tapp, A. Gonzalez, R. Fang, E. J. Mark, J. M. Batten, H. Chen, K. D. Wilner, E. L. Kwak, J. W. Clark, D. P. Carbone, H. Ji, J. A. Engelman, M. Mino-Kenudson, W. Pao and A. J. Iafrate, J. Clin. Oncol., 2012, 30, 863-870.

8 B. Gitlitz, B. Addario, A. Sable-Hunt, S. Novello, T. Vavala, R. Chen, M. Bittoni, S. L. Park, M. Jennings and G. Oxnard, J. Clin. Oncol., 2016, 11, S174.

9 M. Takeda, I. Okamoto and K. Nakagawa, J. Clin. Oncol., 2013, 8, 654-657.

10 X. Pan, T. Lv, F. Zhang, H. Fan, H. Liu and Y. Song, Clin. Transl. Oncol., 2018, 20, 1168-1174.

11 J. F. Gainor, S. H. Ou, J. Logan, L. F. Borges and A. T. Shaw, J. Thorac. Oncol., 2013, 8, 1570-1573.

12 P. W. Sperduto, N. Kased, D. Roberge, Z. Xu, R. Shanley, X. Luo, P. K. Sneed, S. T. Chao, R. J. Weil, J. Suh, A. Bhatt, A. W. Jensen, P. D. Brown, H. A. Shih, J. Kirkpatrick, L. E. Gaspar, J. B. Fiveash, V. Chiang, J. P. Knisely, C. M. Sperduto, N. Lin and M. Mehta, J. Clin. Oncol., 2012, 30, 419-425.

13 K. Deepak, B. Paul, L. Jing and M. P. Mehta, J. Clin. Oncol., 2015, 24, 1295-1304.

14 J. L. Hubbs, J. A. Boyd, H. Donna, J. P. Chino, S. Mert and C. R. Kelsey, Cancer, 2010, 116, 5038-5046.

15 I. B. Muller, A. J. de Langen, E. Giovannetti and G. J. Peters, OncoTargets Ther., 2017, 10, 4535-4541.
16 M. Nishio, D. W. Kim, Y. L. Wu, K. Nakagawa, B. J. Solomon, A. T. Shaw, S. Hashigaki, E. Ohki, T. Usari, J. Paolini, A. Polli, K. D. Wilner and T. Mok, Cancer Res. Treat., 2018, 50, 691-700.

17 A. T. Shaw, D. W. Kim, R. Mehra, D. S. Tan, E. Felip, L. Q. Chow, D. R. Camidge, J. Vansteenkiste, S. Sharma, T. De Pas, G. J. Riely, B. J. Solomon, J. Wolf, M. Thomas, M. Schuler, G. Liu, A. Santoro, Y. Y. Lau, M. Goldwasser, A. L. Boral and J. A. Engelman, N. Engl. J. Med., 2014, 370, 1189-1197.

18 O. Arrieta, L. A. Ramirez-Tirado, R. Baez-Saldana, O. PenaCuriel, G. Soca-Chafre and E. O. Macedo-Perez, Lung Cancer, 2015, 90, 161-166.

19 A. Sgambato, F. Casaluce, P. Maione and C. Gridelli, Expert Rev. Anticancer Ther., 2018, 18, 71-80.

20 J. Remon, E. Le Rhun and B. Besse, Cancer Treat. Rev., 2017, 53, 128-137.

21 C. J. J. A. F. P. A. U. P. U. F. K. M. Eberth, Virchows Arch. A: Pathol. Anat., 1969, 49, 51-63.

22 C. P. Kokkoris, Cancer, 1983, 51, 154-160.

23 J. Yang, S. Shin, M. Fowkes, S. Krieger, J. A. Strauchen, M. Smethurst and A. Demopoulos, J. Neurol., 2011, 77, e75.

24 A. Boire, Y. Zou, J. Shieh, D. G. Macalinao, E. Pentsova and J. Massague, Cell, 2017, 168, 1101-1113.

25 S. S. Lee, M. K. Kim, S. J. Sym, S. W. Kim, W. K. Kim, S. B. Kim and J. H. Ahn, J. Neuro-Oncol., 2007, 84, 85-89.

26 H. Okamoto, T. Shinkai, Y. Matsuno and N. Saijo, Cancer, 2015, 72, 2583-2588.

27 E. S. Connolly Jr, C. J. Winfree, P. C. Mccormick, M. Cruz and B. M. Stein, Surgical Neurology, 1996, 46, 329-337.

28 J. M. Findlay, M. Bernstein, R. G. Vanderlinden and L. Resch, Neurosurgery, 1987, 21, 911.

29 M. Kizawa, N. Mori, Y. Hashizume and M. Yoshida, Neuropathology, 2010, 28, 295-302.

30 K. Steven, P. Johan, L. R. Emilie, P. Fabrice, I. Gueorgui, R. François-Xavier, P. Philippe, M. Jean-François, E. Evelyne and D. Bertrand, Neurosurgery, 2013, 73, 923931.

31 Y. Xu, W. Zhong, J. Zhao, M. Chen, L. Li and M. Wang, Zhongguo Feiai Zazhi, 2016, 19, 539-544.

32 H. Okamoto, T. Shinkai, Y. Matsuno and N. Saijo, Cancer, 2015, 72, 2583-2588.

33 W. S. Sung, M. J. Sung, J. H. Chan, B. Manion, J. Song, A. Dubey, A. Erasmus and A. Hunn, World Neurosurg., 2013, 79, 576-584.

34 M. Karsy, J. Guan, W. Sivakumar, J. A. Neil, M. H. Schmidt and M. A. Mahan, Neurosurg. Focus, 2015, 39, E3.

35 C. Kuijpers, L. E. L. Hendriks, J. L. Derks, A. C. Dingemans, A. S. R. van Lindert, M. M. van den Heuvel, R. A. Damhuis and S. M. Willems, Lung Cancer, 2018, 121, 76-81.

36 L. R. Patel, D. F. Camacho, Y. Shiozawa, K. J. Pienta and R. S. Taichman, Future Oncol., 2011, 7, 1285-1297.

37 S. Peters and E. Meylan, Curr. Opin. Oncol., 2013, 25, 137144.

38 C. D'Antonio, A. Passaro, B. Gori, E. Del Signore, M. R. Migliorino, S. Ricciardi, A. Fulvi and F. de Marinis, Ther. Adv. Med. Oncol., 2014, 6, 101-114. 
39 R. Faccio, Ann. N. Y. Acad. Sci., 2011, 1237, 71-78.

40 W. J. Boyle, W. S. Simonet and D. L. Lacey, Nature, 2003, 423, 337.

41 Y. Y. Kong, H. Yoshida, I. Sarosi, H. L. Tan, E. Timms, C. Capparelli, S. Morony, A. J. Oliveira-Dos-Santos, G. Van and A. Itie, Nature, 1999, 397, 315-323.

42 E. E. Mcgrath, J. Thorac. Oncol., 2011, 6, 1468-1473.

43 G. R. Mundy, Nat. Rev. Cancer, 2002, 2, 584-593.

44 L. Xin, W. Qiongqing, H. Guohong, V. P. Catherine, F. Martin, R. Michael, M. Joan and K. Yibin, Genes Dev., 2009, 23, 1882.

45 R. E. Miller, J. C. Jones, T. Mark, M. L. Blake and W. C. Dougall, J. Thorac. Oncol., 2014, 9, 345-354.

46 D. Jones, E. R. Pereira and T. P. Padera, Front Oncol., 2018, $8,36$.

47 S. Zhang, B. Yan, J. Zheng, J. Zhao and J. Zhou, Oncotarget, 2016, 7, 63758-63766.

48 Q. Gao, H. Ma, B. Wang, Y. Yao, J. Zhou and J. Zhou, Oncotarget, 2017, 8, 108840-108847.

49 J. A. Irving and R. H. Young, Am. J. Surg. Pathol., 2005, 29, 997.

50 K. Fujiwara, Y. Ohishi, H. Koike, S. Sawada, T. Moriya and I. Kohno, Gynecol. Oncol., 1995, 59, 124-128.

51 K. A. Lee, J. S. Lee, J. K. Min, H. J. Kim, W. S. Kim and K. Y. Lee, Tuberc. Respir. Dis., 2014, 77, 258-261.

52 X. Jing, F. Li, X. Meng, Z. Liu, J. Yu and B. Liu, Cancer Biol. Ther., 2017, 18, 279-284.

53 T. Franchina, A. Russo, G. R. Ricciardi, G. Liguori, A. Herberg, N. Normanno and V. Adamo, Cancer Biol. Ther., 2016, 1-5, DOI: 10.1080/15384047.2016.1219822.

54 K. M. Kreusel, N. E. Bechrakis, T. Wiegel, L. Krause and M. H. Foerster, Acta Ophthalmol., 2008, 86, 515-519.

55 Y. Okuma, Y. Hosomi, K. Kitamura, M. Iguchi, T. Okamura, S. Fukami, T. Hishima and M. Shibuya, Int. J. Clin. Oncol., 2009, 14, 541-544.

56 Y. Okuma, Y. Tanaka, T. Kamei, Y. Hosomi and T. Okamura, OncoTargets Ther., 2015, 8, 1321-1325.

57 S. Lu, M. C. Azada and S. H. Ou, Lung Cancer, 2015, 87, 207209.

58 Y. Feng, A. D. Singh, C. Lanigan, R. R. Tubbs and P. C. Ma, J. Thorac. Oncol., 2013, 8, e109-111.

59 Z. H. Cui, Y. Zhang, L. L. Liang, Z. H. Li, I. Abramova and Q. Hao, Int. J. Ophthalmol., 2017, 10, 310-314.

60 R. E. Mikes, F. Jordan, G. Hutarew and M. Studnicka, Lung Cancer, 2015, 90, 614-616.

61 M. Varella-Garcia, J. A. Iafrate and W. Pao, J. Thorac. Oncol., 2011, 6(6), S291.

62 P. Yang, J. Thorac. Oncol., 2011, 6(6), S50.

63 R. C. Doebele, X. Lu, C. Sumey, D. A. Maxson, A. J. Weickhardt, A. B. Oton, P. A. Bunn Jr, A. E. Baron, W. A. Franklin, D. L. Aisner, M. Varella-Garcia and D. R. Camidge, Cancer, 2012, 118, 4502-4511.

64 M. Di, X. Hao, W. Yan, P. Xing and J. Li, Thorac. Cancer, 2016, 7, 452-458.

65 S. Tan, D. Sun, W. Pu, Q. Gou, C. Guo, Y. Gong, J. Li, Y. Q. Wei, L. Liu, Y. Zhao and Y. Peng, Mol. Cancer, 2018, 17, 138.
66 L. Li, Y. Wang, T. Peng, K. Zhang, C. Lin, R. Han, C. Lu and Y. He, Oncotarget, 2016, 7, 34442-34452.

67 J. F. Gainor, L. Dardaei, S. Yoda, L. Friboulet, I. Leshchiner, R. Katayama, I. Dagogo-Jack, S. Gadgeel, K. Schultz, M. Singh, E. Chin, M. Parks, D. Lee, R. H. DiCecca, E. Lockerman, T. Huynh, J. Logan, L. L. Ritterhouse, L. P. Le, A. Muniappan, S. Digumarthy, C. Channick, C. Keyes, G. Getz, D. Dias-Santagata, R. S. Heist, J. Lennerz, L. V. Sequist, C. H. Benes, A. J. Iafrate, M. Mino-Kenudson, J. A. Engelman and A. T. Shaw, Cancer Discovery, 2016, 6, 1118-1133.

68 B. De Craene and G. Berx, Nat. Rev. Cancer, 2013, 13, 97110.

69 A. Kogita, Y. Togashi, H. Hayashi, S. Sogabe, M. Terashima, M. A. De Velasco, K. Sakai, Y. Fujita, S. Tomida, Y. Takeyama, K. Okuno, K. Nakagawa and K. Nishio, Int. J. Oncol., 2014, 45, 1430-1436.

70 F. Guo, X. Liu, Q. Qing, Y. Sang, C. Feng, X. Li, L. Jiang, P. Su and Y. Wang, Biochem. Biophys. Res. Commun., 2015, 459, 398-404.

71 R. An, Y. Wang, D. Voeller, A. Gower, I. K. Kim, Y. W. Zhang and G. Giaccone, Oncotarget, 2016, 7, 29199-29210.

72 H. X. Gao, L. Yan, C. Li, L. M. Zhao and W. Liu, Mol. Med. Rep., 2016, 14, 4135-4143.

73 H. J. Jun, H. Johnson, R. T. Bronson, S. de Feraudy, F. White and A. Charest, Cancer Res., 2012, 72, 3764-3774.

74 W. Gou, X. Zhou, Z. Liu, L. Wang, J. Shen, X. Xu, Z. Li, X. Zhai, D. Zuo and Y. Wu, Cancer Lett., 2018, 422, 19-28.

75 M. A. Socinski, T. Evans, S. Gettinger, T. A. Hensing, L. VanDam Sequist, B. Ireland and T. E. Stinchcombe, Chest, 2013, 143, e341S-e368S.

76 Y. Y. Soon, M. R. Stockler, L. M. Askie and M. J. Boyer, J. Clin. Oncol., 2009, 27, 3277-3283.

77 B. J. Solomon, F. Cappuzzo, E. Felip, F. H. Blackhall, D. B. Costa, D.-W. Kim, K. Nakagawa, Y.-L. Wu, T. Mekhail, J. Paolini, J. Tursi, T. Usari, K. D. Wilner, P. Selaru and T. S. K. Mok, J. Clin. Oncol., 2016, 34, 28582865.

78 J. D. Patel, M. A. Socinski, E. B. Garon, C. H. Reynolds, D. R. Spigel, M. R. Olsen, R. C. Hermann, R. M. Jotte, T. Beck, D. A. Richards, S. C. Guba, J. Liu, B. FrimodtMoller, W. J. John, C. K. Obasaju, E. J. Pennella, P. Bonomi and R. Govindan, J. Clin. Oncol., 2013, 31, 4349-4357.

79 M. J. Edelman, T. Le Chevalier and J. C. Soria, J. Thorac. Oncol., 2012, 7, 1331-1336.

80 J. G. Christensen, H. Y. Zou, M. E. Arango, Q. Li, J. H. Lee, S. R. McDonnell, S. Yamazaki, G. R. Alton, B. Mroczkowski and G. Los, Mol. Cancer Ther., 2007, 6, 3314-3322.

81 H. Yasuda, L. L. de Figueiredo-Pontes, S. Kobayashi and D. B. Costa, J. Thorac. Oncol., 2012, 7, 1086-1090.

82 I. Hideko, Y. Masayuki, T. Nagio, H. Katsuyuki, I. Eiki, T. Akihiko, T. Shinichi, H. Shinsuke, S. Toshiaki and T. Mitsune, Jpn. J. Clin. Oncol., 2014, 44, 963-968.

83 K. Yoshiaki, K. Yasutaka, S. Atsuhiko and H. Kouko, BMJ Case Rep., 2013, 2013, DOI: 10.1136/bcr-2013-200867. 
84 D. Maillet, I. Martellafay, D. Arpin and M. Pérol, J. Thorac. Oncol., 2013, 8, e30-e31.

85 B. J. Solomon, T. Mok, D. W. Kim, Y. L. Wu, K. Nakagawa, T. Mekhail, E. Felip, F. Cappuzzo, J. Paolini, T. Usari, S. Iyer, A. Reisman, K. D. Wilner, J. Tursi, F. Blackhall and P. Investigators, N. Engl. J. Med., 2014, 371, 2167-2177.

86 A. T. Shaw, D. W. Kim, K. Nakagawa, T. Seto, L. Crino, M. J. Ahn, T. De Pas, B. Besse, B. J. Solomon, F. Blackhall, Y. L. Wu, M. Thomas, K. J. O'Byrne, D. Moro-Sibilot, D. R. Camidge, T. Mok, V. Hirsh, G. J. Riely, S. Iyer, V. Tassell, A. Polli, K. D. Wilner and P. A. Janne, N. Engl. J. Med., 2013, 368, 2385-2394.

87 https://www.cancer.gov/about-cancer/treatment/drugs/fdacrizotinib, 2013.

88 J. C. Chuang and J. W. Neal, Transl. Lung Cancer Res., 2015, 4, 639-641.

89 I. Dagogo-Jack and A. T. Shaw, Ann. Oncol., 2016, 27 (suppl. 3), iii42-iii50.

90 G. Toyokawa, T. Seto, M. Takenoyama and Y. Ichinose, Cancer Metastasis Rev., 2015, 34, 797-805.

91 M. Zhang, L. Nie and J. Zhang, Zhongguo Feiai Zazhi, 2016, 19, 525-529.

92 C. E. Onesti, D. Iacono, S. Angelini, M. Mazzotta, R. Giusti, S. Lauro and P. Marchetti, Anticancer Drugs, 2019, 30, 201-204.

93 S. Okawa, T. Shibayama, A. Shimonishi, J. Nishimura, T. Ozeki, K. Takada, H. Kayatani, D. Minami, K. Sato, K. Fujiwara, T. Yonei, T. Sato and M. Suno, Case Rep. Oncol., 2018, 11, 777-783.

94 K. Hideki, N. Takahiro, T. Kengo, S. Manabu, M. Hiroyuki, I. Toshihiko, M. Yukiko, Y. Mitsuru, S. Masato, I. Meiji, I. Makiko, I. Dai, Y. Sana, K. Hajime, O. Miki and N. Akira, Lung Cancer, 2012, 75, 66-72.

95 L. Friboulet, N. Li, R. Katayama, C. C. Lee, J. F. Gainor, A. S. Crystal, P. Y. Michellys, M. M. Awad, N. Yanagitani, S. Kim, A. C. Pferdekamper, J. Li, S. Kasibhatla, F. Sun, X. Sun, S. Hua, P. McNamara, S. Mahmood, E. L. Lockerman, N. Fujita, M. Nishio, J. L. Harris, A. T. Shaw and J. A. Engelman, Cancer Discovery, 2014, 4, 662-673.

96 D. W. Kim, R. Mehra, S. W. Tan, E. Felip, L. Q. M. Chow and D. R. Camidge, Oncologist, 2014, 19, 5-11.

97 I. Zhang, N. G. Zaorsky, J. D. Palmer, R. Mehra and B. Lu, Lancet Oncol., 2015, 16, e510-e521.

98 S. M. Lim, H. R. Kim, J. S. Lee, K. H. Lee, Y. G. Lee, Y. J. Min, E. K. Cho, S. S. Lee, B. S. Kim and M. Y. Choi, J. Clin. Oncol., 2017, 35, 2613.

99 Y. Xu, W. Zhong, M. Chen, J. Zhao and M. Wang, Thorac. Cancer, 2018, 9, 1078-1081.

100 E. Bendaly, A. A. Dalal, K. Culver, P. Galebach, I. Bocharova, R. Foster, M. Sasane, A. R. Macalalad and A. Guérin, Adv. Ther., 2017, 34, 1145.

101 S. M. Gadgeel, L. Gandhi, G. J. Riely, A. A. Chiappori, H. L. West, M. C. Azada, P. N. Morcos, R. M. Lee, L. Garcia and L. J. Yu, Lancet Oncol., 2014, 15, 1119-1128.

102 T. Kodama, M. Hasegawa, K. Takanashi, Y. Sakurai, O. Kondoh and H. Sakamoto, Cancer Chemother. Pharmacol., 2014, 74, 1023-1028.
103 H. Sakamoto, T. Tsukaguchi, S. Hiroshima, T. Kodama, T. Kobayashi, T. A. Fukami, N. Oikawa, T. Tsukuda, N. Ishii and Y. Aoki, Cancer Cell, 2011, 19, 679-690.

104 https://www.cancer.gov/news-events/cancer-currents-blog/ 2017/alectinib-fda-untreated-lung-cancer, 2017.

105 S. Peters, D. R. Camidge, A. T. Shaw, S. Gadgeel, J. S. Ahn, D. W. Kim, S. I. Ou, M. Perol, R. Dziadziuszko, R. Rosell, A. Zeaiter, E. Mitry, S. Golding, B. Balas, J. Noe, P. N. Morcos and T. Mok, N. Engl. J. Med., 2017, 377, 829-838.

106 J. F. Gainor, C. A. Sherman, K. Willoughby, J. Logan, E. Kennedy, P. K. Brastianos, A. S. Chi and A. T. Shaw, J. Thorac. Oncol., 2015, 10, 232-236.

107 S. H. Ou, J. S. Ahn, L. De Petris, R. Govindan, J. C. Yang, B. Hughes, H. Lena, D. Moro-Sibilot, A. Bearz, S. V. Ramirez, T. Mekhail, A. Spira, W. Bordogna, B. Balas, P. N. Morcos, A. Monnet, A. Zeaiter and D. W. Kim, J. Clin. Oncol., 2016, 34, 661-668.

108 I. O. Sai-Hong, K. R. Sommers, M. C. Azada and E. B. Garon, Oncologist, 2015, 20, 224-226.

109 A. Markham, Drugs, 2017, 77, 1131-1135.

110 D. R. Camidge, H. R. Kim, M. J. Ahn, J. C. Yang, J. Y. Han, J. S. Lee, M. J. Hochmair, J. Y. Li, G. C. Chang, K. H. Lee, C. Gridelli, A. Delmonte, R. Garcia Campelo, D. W. Kim, A. Bearz, F. Griesinger, A. Morabito, E. Felip, R. Califano, S. Ghosh, A. Spira, S. N. Gettinger, M. Tiseo, N. Gupta, J. Haney, D. Kerstein and S. Popat, N. Engl. J. Med., 2018, 379, 2027-2039.

111 D. W. Kim, M. Tiseo, M. J. Ahn, K. L. Reckamp, K. H. Hansen, S. W. Kim, R. M. Huber, H. L. West, G. Hjm and M. J. Hochmair, J. Clin. Oncol., 2017, 35, JCO2016715904.

112 S. N. Gettinger, L. A. Bazhenova, C. J. Langer, R. Salgia, K. A. Gold, R. Rosell, A. T. Shaw, G. J. Weiss, M. Tugnait, N. I. Narasimhan, D. J. Dorer, D. Kerstein, V. M. Rivera, T. Clackson, F. G. Haluska and D. R. Camidge, Lancet Oncol., 2016, 17, 1683-1696.

113 T. W. Johnson, P. F. Richardson, S. Bailey, A. Brooun, B. J. Burke, M. R. Collins, J. J. Cui, J. G. Deal, Y. L. Deng, D. Dinh, L. D. Engstrom, M. He, J. Hoffman, R. L. Hoffman, Q. Huang, R. S. Kania, J. C. Kath, H. Lam, J. L. Lam, P. T. Le, L. Lingardo, W. Liu, M. McTigue, C. L. Palmer, N. W. Sach, T. Smeal, G. L. Smith, A. E. Stewart, S. Timofeevski, H. Zhu, J. Zhu, H. Y. Zou and M. P. Edwards, J. Med. Chem., 2014, 57, 4720-4744.

114 https://www.cancer.gov/news-events/cancer-currents-blog/ 2017/fda-ceritinib-nsclc, 2017.

115 H. Y. Zou, L. Friboulet, D. P. Kodack, L. D. Engstrom, Q. Li, M. West, R. W. Tang, H. Wang, K. Tsaparikos, J. Wang, S. Timofeevski, R. Katayama, D. M. Dinh, H. Lam, J. L. Lam, S. Yamazaki, W. Hu, B. Patel, D. Bezwada, R. L. Frias, E. Lifshits, S. Mahmood, J. F. Gainor, T. Affolter, P. B. Lappin, H. Gukasyan, N. Lee, S. Deng, R. K. Jain, T. W. Johnson, A. T. Shaw, V. R. Fantin and T. Smeal, Cancer Cell, 2015, 28, 70-81.

116 M. Nishio, K. Nakagawa, T. Mitsudomi, N. Yamamoto, T. Tanaka, H. Kuriki, A. Zeaiter and T. Tamura, Lung Cancer, 2018, 121, 37-40. 
117 T. Hida, H. Nokihara, M. Kondo, Y. H. Kim, K. Azuma, T. Seto, Y. Takiguchi, M. Nishio, H. Yoshioka and F. Imamura, Lancet, 2017, 390, 29-39.

118 A. T. Shaw, E. Felip, T. M. Bauer, B. Besse, A. Navarro, S. Postel-Vinay, J. F. Gainor, M. Johnson, J. Dietrich, L. P. James, J. S. Clancy, J. Chen, J.-F. Martini, A. Abbattista and B. J. Solomon, Lancet Oncol., 2017, 18, 1590-1599.

119 T. Li, W. Ma and E. C. Tian, Chin. J. Clin. Oncol., 2018, DOI: 10.21037/cco.2018.10.12.

120 L. Horn, J. R. Infante, K. L. Reckamp, G. R. Blumenschein, T. A. Leal, S. N. Waqar, B. J. Gitlitz, R. E. Sanborn, J. G. Whisenant, L. Du, J. W. Neal, J. P. Gockerman, G. Dukart, K. Harrow, C. Liang, J. J. Gibbons, A. Holzhausen, C. M. Lovly and H. A. Wakelee, Clin. Cancer Res., 2018, 24, 2771-2779.

121 T. Yosuke, M. Katsuhiro, F. Masahide, T. Tomohiro, F. Shiro, I. Kaoru, S. Yuichi, K. Young Hak, M. Tadashi and I. Ken-Ichi, J. Thorac. Oncol., 2010, 5, 950-955.

122 Q. Wei-Xiang, S. Zan, L. Feng, S. Yuan-Jue, M. Da-Liu, T. LiNa, H. Ai-Na and Y. Yang, Asian Pac. J. Cancer Prev., 2012, 13, 5177-5182.

123 Y. Chikaishi, M. Kanayama, A. Taira, Y. Nabe, S. Shinohara, T. Kuwata, M. Takenaka, S. Oka, A. Hirai, K. Kuroda, N. Imanishi, Y. Ichiki and F. Tanaka, Ann. Transl. Med., 2018, 6, 401.

124 K. Ota, K. Azuma, A. Kawahara, S. Hattori, E. Iwama, J. Tanizaki, T. Harada, K. Matsumoto, K. Takayama, S. Takamori, M. Kage, T. Hoshino, Y. Nakanishi and I. Okamoto, Clin. Cancer Res., 2015, 21, 4014-4021.

125 K. Azuma, K. Ota, A. Kawahara, S. Hattori, E. Iwama, T. Harada, K. Matsumoto, K. Takayama, S. Takamori and M. Kage, Ann. Oncol., 2014, 25, 1935.

126 E. A. Akbay, S. Koyama, J. Carretero, A. Altabef, J. H. Tchaicha, C. L. Christensen, O. R. Mikse, A. D. Cherniack, E. M. Beauchamp, T. J. Pugh, M. D. Wilkerson, P. E. Fecci, M. Butaney, J. B. Reibel, M. Soucheray, T. J. Cohoon, P. A. Janne, M. Meyerson, D. N. Hayes, G. I. Shapiro, T. Shimamura, L. M. Sholl, S. J. Rodig, G. J. Freeman, P. S. Hammerman, G. Dranoff and K. K. Wong, Cancer Discovery, 2013, 3, 1355-1363.

127 H. Borghaei, L. Paz-Ares, L. Horn, D. R. Spigel, M. Steins, N. E. Ready, L. Q. Chow, E. E. Vokes, E. Felip, E. Holgado, F. Barlesi, M. Kohlhaufl, O. Arrieta, M. A. Burgio, J. Fayette, H. Lena, E. Poddubskaya, D. E. Gerber, S. N. Gettinger, C. M. Rudin, N. Rizvi, L. Crino, G. R. Blumenschein Jr, S. J. Antonia, C. Dorange, C. T. Harbison, F. Graf Finckenstein and J. R. Brahmer, N. Engl. J. Med., 2015, 373, 1627-1639.

128 M. Protopapa, V. Kouloulias, S. Nikoloudi, C. Papadimitriou, G. Gogalis and A. Zygogianni, J. Oncol., 2019, 2019, 3267409.

129 M. A. Socinski, R. M. Jotte, F. Cappuzzo, F. Orlandi, D. Stroyakovskiy, N. Nogami, D. Rodriguez-Abreu, D. Moro-Sibilot, C. A. Thomas, F. Barlesi, G. Finley, C. Kelsch, A. Lee, S. Coleman, Y. Deng, Y. Shen,
M. Kowanetz, A. Lopez-Chavez, A. Sandler and M. Reck, N. Engl. J. Med., 2018, 378, 2288-2301.

130 L. Fehrenbacher, A. Spira, M. Ballinger, M. Kowanetz, J. Vansteenkiste, J. Mazieres, K. Park, D. Smith, A. ArtalCortes, C. Lewanski, F. Braiteh, D. Waterkamp, P. He, W. Zou, D. S. Chen, J. Yi, A. Sandler and A. Rittmeyer, Lancet, 2016, 387, 1837-1846.

131 A. Rittmeyer, F. Barlesi, D. Waterkamp, K. Park, F. Ciardiello, J. von Pawel, S. M. Gadgeel, T. Hida, D. M. Kowalski, M. C. Dols, D. L. Cortinovis, J. Leach, J. Polikoff, C. Barrios, F. Kabbinavar, O. A. Frontera, F. De Marinis, H. Turna, J. S. Lee, M. Ballinger, M. Kowanetz, P. He, D. S. Chen, A. Sandler and D. R. Gandara, Lancet, 2017, 389, 255-265.

132 FDA expands approved use of Opdivo to treat lung cancer, Press release of the Food and Drug Administration, Bethesda, MD, 2015, http://www.fda.gov/newsevents/ newsroom/pressannouncements/ucm436534.htm.

133 J. Brahmer, K. L. Reckamp, P. Baas, L. Crinò, W. E. E. Eberhardt, E. Poddubskaya, S. Antonia, A. Pluzanski, E. E. Vokes, E. Holgado, D. Waterhouse, N. Ready, J. Gainor, O. Arén Frontera, L. Havel, M. Steins, M. C. Garassino, J. G. Aerts, M. Domine, L. Paz-Ares, M. Reck, C. Baudelet, C. T. Harbison, B. Lestini and D. R. Spigel, N. Engl. J. Med., 2015, 373, 123-135.

134 C. J. Langer, S. M. Gadgeel, H. Borghaei, V. A. Papadimitrakopoulou, A. Patnaik, S. F. Powell, R. D. Gentzler, R. G. Martins, J. P. Stevenson, S. I. Jalal, A. Panwalkar, J. C.-H. Yang, M. Gubens, L. V. Sequist, M. M. Awad, J. Fiore, Y. Ge, H. Raftopoulos and L. Gandhi, Lancet Oncol., 2016, 17, 1497-1508.

135 S. B. Goldberg, S. N. Gettinger, A. Mahajan, A. C. Chiang, R. S. Herbst, M. Sznol, A. J. Tsiouris, J. Cohen, A. Vortmeyer, L. Jilaveanu, J. Yu, U. Hegde, S. Speaker, M. Madura, A. Ralabate, A. Rivera, E. Rowen, H. Gerrish, X. Yao, V. Chiang and H. M. Kluger, Lancet Oncol., 2016, 17, 976-983. 136 S. D. Kamath and P. U. Kumthekar, Front Oncol., 2018, 8, 414.

137 J. Larkin, V. Chiarion-Sileni, R. Gonzalez, J. J. Grob, C. L. Cowey, C. D. Lao, D. Schadendorf, R. Dummer, M. Smylie, P. Rutkowski, P. F. Ferrucci, A. Hill, J. Wagstaff, M. S. Carlino, J. B. Haanen, M. Maio, I. Marquez-Rodas, G. A. McArthur, P. A. Ascierto, G. V. Long, M. K. Callahan, M. A. Postow, K. Grossmann, M. Sznol, B. Dreno, L. Bastholt, A. Yang, L. M. Rollin, C. Horak, F. S. Hodi and J. D. Wolchok, N. Engl. J. Med., 2015, 373, 1270-1271.

138 M. A. Gubens, L. V. Sequist, J. P. Stevenson, S. F. Powell, L. C. Villaruz, S. M. Gadgeel, C. J. Langer, A. Patnaik, H. Borghaei, S. I. Jalal, J. Fiore, S. Saraf, H. Raftopoulos and L. Gandhi, Lung Cancer, 2019, 130, 59-66.

139 S. Hernandez-Duran, S. Hanft, R. J. Komotar and G. R. Manzano, Neurosurgical Review, 2016, 39, 175-183.

140 H. K. Ahn, B. Han, S. J. Lee, T. Lim, J. M. Sun, J. S. Ahn, M. J. Ahn and K. Park, Lung Cancer, 2012, 76, 253-254.

141 J.-C. Soria, D. S. W. Tan, R. Chiari, Y.-L. Wu, L. Paz-Ares, J. Wolf, S. L. Geater, S. Orlov, D. Cortinovis, C.-J. Yu, 
M. Hochmair, A. B. Cortot, C.-M. Tsai, D. Moro-Sibilot, R. G. Campelo, T. McCulloch, P. Sen, M. Dugan, S. Pantano, F. Branle, C. Massacesi and G. de Castro, Lancet, 2017, 389, 917-929.

142 M. Reck, Immunotherapy, 2018, 10, 93.

143 R. Hui, E. B. Garon, J. W. Goldman, N. B. Leighl, M. D. Hellmann, A. Patnaik, L. Gandhi, J. P. Eder, M. J. Ahn and L. Horn, Ann. Oncol., 2017, 28, 874-881.

144 T. Hida, H. Nokihara, M. Kondo, Y. H. Kim, K. Azuma, T. Seto, Y. Takiguchi, M. Nishio, H. Yoshioka, F. Imamura, K. Hotta, S. Watanabe, K. Goto, M. Satouchi, T. Kozuki, T. Shukuya, K. Nakagawa, T. Mitsudomi,
N. Yamamoto, T. Asakawa, R. Asabe, T. Tanaka and T. Tamura, Lancet, 2017, 390, 29-39.

145 D. R. Camidge, D. W. Kim, M. Tiseo, C. J. Langer, M. J. Ahn, A. T. Shaw, R. M. Huber, M. J. Hochmair, D. H. Lee, L. A. Bazhenova, K. A. Gold, S. I. Ou, H. L. West, W. Reichmann, J. Haney, T. Clackson, D. Kerstein and S. N. Gettinger, J. Clin. Oncol., 2018, 36, 2693-2701.

146 B. J. Solomon, B. Besse, T. M. Bauer, E. Felip, R. A. Soo, D. R. Camidge, R. Chiari, A. Bearz, C. C. Lin, S. M. Gadgeel, G. J. Riely, E. H. Tan, T. Seto, L. P. James, J. S. Clancy, A. Abbattista, J. F. Martini, J. Chen, G. Peltz, H. Thurm, S. I. Ou and A. T. Shaw, Lancet Oncol., 2018, 19, 1654-1667. 